International Journal of Current Aspects, Volume 3, Issue IV, 2019, PP 150-156, ISSN 2616-6976 iJCAB

\title{
Youth Participation in Forestry Education in Nigeria
}

\author{
Areo Olusola Samuel*, Oyewale, O. O., and Oyewumi, O.R. \\ Forestry Research Institute of Nigeria, Ibadan \\ *Correspondent Author e-mail:areosola73@gmail.com
}

\begin{abstract}
Forest contributes immensely to the socio-economic well-being of man especially in the developing world while the role of forestry education is critical to national development and multifaceted to the foresters, technologist and artisans. Due to constant changes and technological advancement, forestry education must be repositioned to be more adaptable, flexible and evolving to meet the present contemporary challenges in student's enrolment to the present 20 Universities and 7 Colleges offering forestry and allied course in Nigeria. This paper examined the participation of youth in forestry education towards achieving developmental and sustainability issues of forest future in Nigeria. This investigation, therefore, concluded that there is urgent attention for mass enlightenment and sensitization on forestry education and their benefits. It's important also for forestry education to be rebranded to make it more attractive, encouraging and interesting to the student, boosting enrollment and future career options. Curricula of forestry courses need to be urgently reviewed in secondary schools and new methodology should be introduced into the curriculum. The government should ensure adequate support and funding, forestry teachers should further undergo both formal and informal training to enhance effective teaching and practical delivery. Forestry education should, therefore, a metamorphosis from the present theory-based learning process to practical oriented training.
\end{abstract}

Key Words: Youth Participation, Forestry, Education, Oyo State

DOI: 10.35942/ijcab.v3iIV.53 URN: urn:nbn:de:0000ijcab.v3iIV.535

\section{Cite this Article:}

Areo, S., Oyewale, O., \& Oyewumi, O. (2019). Youth Participation in Forestry Education in Nigeria. International Journal of Current Aspects, 3(IV), 150-156. https://doi.org/10.35942/ijcab.v3iIV.53

\section{INTRODUCTION}

From the human angle, the forests have been exploited for timber, food, medicine, fuelwood, poles, pest, vegetables, and canes wildlife, among others without a corresponding replacement. The expansion of agricultural land for increased food production has put the existing forest in danger. Urban and infrastructural development has also put pressure on the continued existence of the forests. The forests today are facing a bleak future as a result of depletion and mismanagement (Akande and Larinde, 2004) Forestry is the science and craft of creating, managing, using, conserving, and repairing forests and associated resources to meet desired goals, needs, and values for human and environment benefits. Forestry is practiced in plantations and natural stands. (Daramola, 2010) The science of forestry has elements that belong to the biological, physical, social, political and managerial sciences. A forest is a large area dominated by trees. Hundreds of more precise definitions of forest are used throughout the world, 
incorporating factors such as tree density, tree height, land use, legal standing, and ecological function. According to the widely used Food and Agriculture Organization definition, forests covered four billion hectares (15 million square miles) or approximately 30 percent of the world's land area in 2006 (Alao, 2005). Forestry concluded by this review as the science or practice of planting, managing, conserving and maintaining forests and its associated resources with the aim to meet the goal of human benefit. (Chomini, 2011)

Forest is a very important part of the ecosystem. Therefore, management of forest is required and is done by the foresters (forest professionals) (Daramola, 2011). Forestry education was and is still pivotal to national development. The full fledge forestry education began in Ibadan in 1963, but forestry is now offered by many Universities, Colleges and Vocational training institutes in Nigeria. Nigeria professional foresters were rare before 1960 when Nigeria became independent from the British. (Adeyoju 2001). The new freedom calls for development in all sectors of the country's economy including the forestry sector, but among the numbers of forester needed only 27 of 82 professional foresters in the country as at then were Nigerians, this calls for the need for a home-grown forester which was imperative as those trained abroad could not manage tropical ecosystem successfully. The University of Ibadan (UI) was the first University to offer forestry education in Nigeria-it was at a time the regional training centre for forestry, and students from other African Countries were also trained at UI. Virtually all home-grown foresters before 1977 graduated from UI. A however recent educational revolution has enhanced the commencement of forestry education in many institutions (Daramola, 2010)

The level of awareness in forestry is low to the extent that a considerable amount of people known nothing or little about forestry in view of this awareness programmes must be planned as a trained and well-experienced forestry extension worker will be required to carry out the job. In the 70s, powerful attention was focused on the problem of forestry awareness in Nigeria and this led to the formation of Young Forester's Club among the youth as a way of making forestry to get popular among the youth (Agbogidi and Eshegbeyi, 2007). The role of awareness in forestry is broader than the traditional role, which it plays in, other professions. Due to the relatively greater number of human relations based on problems in forestry, the training required for forestry awareness among youth is by far more complex than that of agricultural awareness which is well known to the youth. The creation of awareness of forestry programme in this country can be explained as an informal educational programme which is aimed to Inform all categories of people from different works of life and areas like rural dwellers, urban dwellers and others, the need to manage our forest resources judiciously on sustain yield basis integrate trees into the farming system and also cultivate the idea of planting trees (Agbogidi and Eshegbeyi, 2007). According to Poore and Sayer (2011), essential goods and climate which is being moderated both locally and globally. They influence the compassion and heat retaining capacity of the atmosphere and heat and water exchange characteristics of the earth surface. Also the production of timber and non-timber products as a sustainable yield of wood product for domestic use both by local communities and in country at large and in many cases, it is very important for the generation to export earnings and also the maintenance of wildlife, forest support fish and wildlife which are of vital good sources for local communities and provide a basis for industry, sports, and recreation among others. 


\section{RESEARCH PROBLEM}

Students are faced with the problem of indecision when they are about to choose a career, as a result of differences in opinion from various angles. This problem has plagued many Nigerian secondary school students for quite some time. It is such a problem that must be looked into, knowing full well that the place of secondary education cannot be over emphasized in the educational development of a nation. With good background, students still need to develop themselves on the subject areas they are keenly interested in and particularly that he has potentially for. Lots of students have been found choosing subjects for senior school certificate examination not minding the aspect of their potentiality and the directive of the school counselor (where available). Hence, the study was carried out to find out youth participation in forestry education in Nigeria and further stressed the factors influencing choices and proffers a way forward.

\section{OBJECTIVES}

The Objectives of this research are to:

$>$ Identify the youth participation in forestry education in Nigeria

$>$ Identify factor militating against the choice of forestry as a career

\section{TRENDS IN FORESTRY EDUCATION IN NIGERIA}

Forestry is not only about trees; it is about the whole forestry environment and individuals trained to manage the forest resource (Alao, 2005). Professional forestry education started on 2nd October 1963 (Wyatt-smith and Redhead, 1988) at the University of Ibadan, Nigeria while technical/vocational forestry education commenced formally on the 1st of May, 1941 (Soladoye, 1999) from the Federal College of Forestry, Ibadan, Nigeria. The importance of forestry as a tool for socio-economic development and its recognition as a pivot to environmental stability has led to the establishment of more institutions offering forestry as a degree programme (Akande and Larinde 2004).

Table 1: Universities based on the category of ownership offering professional forestry and allied education in Nigeria

\begin{tabular}{ll}
\hline University/Ownership & Number/Frequency \\
\hline Federal & $11(55 \%)$ \\
State & $06(30 \%)$ \\
Private & $03(15 \%)$ \\
Total & $20(100 \%)$ \\
\hline
\end{tabular}

Source: Joint Admission and Matriculation Board (JAMB) 2017

There are presently about twenty (20) universities out of seventy-two (72) in Nigeria offering professional forestry and allied courses. This figure represents $27.8 \%$ of the total.

\section{EXTENSION EDUCATION AND LEVEL OF AWARENESS IN FORESTRY AMONG STUDENTS}

Extension in its broad sense may be defined as the extending of Services or systems, which extends the educational advantages of an institution to a person unable to avail themselves in a normal manner. Forestry extension has been explained as a system of non-formal education carrying scientific and practical information about forestry and foresters to the rural people, especially to the Taungya farmers. It is therefore designed to bring changes in attitude, skills or 
knowledge of the individuals (Dada, 2008). The primary aim of extension work is to teach people how to raise their standard of living by their own effort using their own resources or manpower and material with assistance from the government. The role of extension education of forestry in the upliftment of the level of awareness of forestry should be practically assisted by the government as the extension programme is bound to create new ideas and thought in the mind of the youth and thus making them jettison the old ideas they are carrying. Dada (2008) indicated that there is a need for various forestry departments to encourage the foster the formation of clubs and more associations which are composed of people from all works of life. He stated further that influential members of the community can join the clubs. The forestry department should help in the formation of the club and come up with elaborate strategies involving the youth. Dada (1983) stated that most attitudes are formed early in life. He said that by way of extending forest education, the youth will have a full glance of what forestry contains and that the youth are future parents and with fundamental respects for the forest and its resources, they too can help in teaching their children in the future. The level of awareness of forestry could only be raised when the entire Department of Forestry and Forestry Research Institute of Nigeria helps vigorously in extending forestry education and thus changing the orientation of youth about forestry and foresters. Forest is one of the natural resources found by a man in his natural environment unlike other material like oil, metal, etc, trees occupy a unique position in that they are renewable resources if wisely used, the resources are inexhaustible (Chomini et al., 2011). The extension services units, therefore, have a lot of information to pass to the public on erosion control, forest fire prevention, love of nature, recreation and what forest and foresters are all about, with all these put together, the level of awareness will be pushed some steps forward.

\section{PARTICIPATION OF YOUTHS IN FORESTRY ACTIVITIES}

Egbhuche and Adeleke (2005) defined participation as an individual or group who has an interest in the use and management of the natural resource base. This can include local resource users and owners (for example hunters farmers, loggers, and harvesters) youths, government officials, planners, extension workers, representatives of industries, indigenous and non-governmental organization (NGO's and other Group). The participation approach to forestry programmed in Oyo state was noticeably extended to secondary schools towards the end of the '70s through the information of forester's club by the Federal Department of Forestry (FDF). Members of this forester's club were exposed to forestry environment such as engagement in field trips and tours to areas of forestry importance and members from different opportune to meet and deliberate on forestry issues. More so, we have an example of the participatory approach to forestry programmes in Ogun state where tree seedling was distributed to school farmers and all the interested public for planting and the young forester's club was instituted in (33) secondary schools.

\section{THE NEED FOR YOUTH PARTICIPATION IN FORESTRY ACTIVITIES}

An approach, which can guarantee the continuity of community participation in forestry, is the involvement of youth. The youth are a group of young people that can be motivated and or indirectly enforced to generate interest in forestry. Generally, youth represents a large proportion of the society that can be collectively addressed and initiated. The involvement of youth in forestry should be one of the important ways to foster forestry development in African; especially Nigeria in view of this, effort should be made towards the continuation of forest 
International Journal of Current Aspects, Volume 3, Issue IV, 2019, PP 150-156, ISSN 2616-6976

iJCAB

practice in Nigeria. In the year 1988, a programme was initiated in Osun State with the objectives of promoting awareness of forestry among school children on the cause and effort of environmental degradation. This was achieved through the formation of young Foresters Club in secondary schools within the projected area. The programme is being supervised by an extension superintendent (Daramola, 2010). For continuity, community participation in forestry to reach the desired goals which could be sustained in perpetuity, the deep involvement of youth, in general, is inevitable. Apart from the main fact that youth represents a very large percentage of Nigeria society, the group cut across the diverse classes that make up the community and in terms of gender, both males and females are almost represented (Daramola, 2010)

\section{THE ROLE OF FORESTRY IN THE DEVELOPMENT OF THE COUNTRY}

In the Nigeria economy, the transformation from barter to a monetary economy and sub sequential awakening forestry and forest service's has helped in the economic growth of the country (Adeyoju, 2001). In contrast of the development of the nation through forestry, it could be clearly seen that petroleum has contributed about $90 \%$ of the economic growth of the Nigeria economy in recent years and it has been the pacemaker and also in addition to the exportation of timber and other forest products which helps in the mainstay of the country's favorable balance of payment. The gap between supply and demand for forest products in Nigeria is enormous (Sene, 2000). The demand for fuelwood and industrial was estimated at 8.9 million cubic meters and 13.3 million cubic meters by the year 2000 and 2020 respectively (Omoluabi, 2011) and FAO, (2012). The demand for wood will continue to increase due to the increase in population and rise in the expectation of people. The estimation of forest resources in Nigeria and the contribution to the National Economy (Wood demand) is inevitable. If forestry development was to become a significant factor in community development, understanding its potential and initiative for its production must be stimulated at the level of the society. Consequently, the natural resources available to the nation might be able to support the production of saleable output thereby providing each income which will contribute to greater good, security and a better standard of living. Adeyoju, (2001) found that the provision of the infrastructural requirement e.g roads, hospitals, electricity, schools and some other social amenities in part of the society of Nigeria are due to forestry activities. Temu, A. and Ogweno, D. (2007) in summation of the role of forestry to our society's stabilization and development looked at forestry as the producer of wood needed on the farm supplement to earnings of funds from forest crops, the revealer of economic fluctuation.

\section{NEED FOR MANAGEMENT OF THE FOREST}

Management of forest resources in Nigeria is essential because Nigeria is once a significant exporter of timber becoming an importer of forest product, costing the country more than US\$210 million annually (FAO, 2007). Nigeria must manage her resources whether on a large or small programme or in a large or small company or in a large or small nation, there's an increase in awareness of the requirement for non-precise resources commitments, resources allocation and resources management (FAO, 2007). Forest also provides other products such as ropes, mushrooms and all other species of animals, which make up the wildlife population popularly known as bush meat. Both groups of a component of the forest ecosystems interact for their natural benefits and mutual co-existence and so ensure a balance. The protective functions of the forest refer to the intangible benefits and it is largely ignored even by the most seemingly knowledgeable group in the society, the forest performs irreplaceable ecological services and 
they assist in the global cycling of water, oxygen carbon and nitrogen. They stabilized the hydrological system, reduced the severity of floods and regulate recharge of springs, streams and underground water. Trees protect the soil on slopes and keep sand from blowing off deserts. Forest houses millions of plant and animal species that will disappear if the forests are destroyed. Forest plays a vital role in the life of people and animals. Forestry itself could be referred to as the scientific management of the forest for the continuous supply of goods and services, which it can produce for the maximum benefit of the people.

\section{CONCLUSION}

The emphasis of this study is trying to find out how youths see forestry and what they feel about choosing it as a career. The future of forestry as a profession, as indeed in all professions largely depends on the formal education process. The training that our students receive will be a decisive factor in their future professional endeavors. Educators, as well as students, must accept continual genuine criticisms and try to introduce the necessary reforms to the curricula in order to remedy specific shortcomings whenever they arise. This will strengthen forestry education and make it flexible and adaptable to the changing needs and reflect concerns of integrated sustainable forestry development including socioeconomic issues. It is also important to state clearly that forestry training at all levels for all cadres should be properly institutionalized and appropriately delivered whenever required. Therefore, it is important that the forest is given maximum protection and care through forestry education to enable it to perform its beneficial services to both man and the environment.

\section{RECOMMENDATION}

From the study, there is a great need to educate the youth about the importance of forestry. In spite of the fact that a lot of resources are derived from the forest, people still destroy them out of ignorance. Therefore, it is necessary to educate and enlighten the public through the youth, so that future mishap can be checked. It is suggested that further work should be done to make sure that forestry is well impacted by our youth so that we will have enough hands to take care of our forests in the future. Also, area such as the role which extension services can play in changing the negative attitudes of youth towards forestry should be looked into for better conservation of forest. In addition, conservation education should be included in the regular curriculum of school right from the primary schools to secondary schools. For this preparation, the forestry department should be linked with education in order to put into the mind of people especially the youth, the need to conserve the forest which should involve practical outing to parks (games reserve), forest reserves, etc. All woodwork as an aspect of introductory technology should be encouraged. Finally, there are also opportunities to develop a career in forest education. With increasing environmental concerns, it's essential that people's understanding of the necessity for woodland and forests is developed. Careers in this area can revolve around public awareness initiatives and direct teaching activities in schools and learning centers.

\section{REFERENCES}

Adeyoju, S.K. (2001): Forestry for National Development: A critique of the Nigerian situation. Proceeding of the 27th Annual Conference of the Forestry Association of Nigeria, September 2001; Abuja. Pp 55-68.

Agbogidi, O.M, and Eshegbeyi, O.F (2007): Forestry for safe Environment. Forest and Forest product society proceedings in J.C Onyekwelu, V.A.J Adekunle and O.Oke (ed) Pp 9698. 
International Journal of Current Aspects, Volume 3, Issue IV, 2019, PP 150-156, ISSN 2616-6976

[iJCAB

Alao, J. S. (2005): Capacity building modules in the Nigerian forest services. Ph.D. Thesis to the University of Ibadan. Ibadan 301p.

Akande, J.A, and Larinde, S.L (2004): Agriculture and Forestry Education in Nigeria. The critical Challenges. Journal of Forestry Research and Management, Pp 45-59

Chomini, E.A, Omoayena, B.O and Chomini, M.S. (2011): Forestry Education: A Necessary Step to Environmental Sustainability. Proceedings of the 34th Annual conference of the Forestry Association of Nigeria held at Osogbo, Osun State. Pp 306-309

Dada, G.O.B. (2008): Communication Strategies for bringing Forestry information and Research Findings to the public Nigeria. An Unpublished Master of Communication Arts Degree Thesis, Cornell University Ithaca, USA

Dada, G.O. B. (1983): The challenge in the management of Renewable Natural Resources in the 80 's special reference to forestry. An invited lecture prepares and delivered to the Tree Club, University of Ibadan.

Daramola, T.M (2010): Forestry education in Africa. State and prospect, the outcome of the discussion at the northern African regional meeting of the International Forestry Students' Association (IFSA). At 18th Commonwealth Forestry Conference.

Egbuche, U.P, and Adeleke, A. (2005): Organization in community participation: Experience on Okomu Forest Reserve, Benin, Edo State. Paper presented at the Forestry Association of Nigeria Conference.

Food and Agriculture Organization. (2007). State of the World's forests. FAO, Rome. Pp 154, http://www.fao.org/docrep/011/i0350e/i035e00.htm

Food and Agriculture Organization. (2012): Reports on forestry industries in Nigeria. Working Document, No. 12A Federal Department of Forestry, Lagos. 17pp

Omoluabi A.C. (2011): Nigeria Forestry Sub-sector. Demand and Supply Report prepared for the Federal Agricultural Coordinating Unit (FACU), Ibadan

Poore, D, and Sayer, J. (2011): The Management of Tropical/Moist Forest. IUCM. Land Ecological Guidelines (2nd). pp 98-101.

Sene, E.H (2000): Forest and Food Security in Africa: the place of forestry in FAO's special programme food security, forests, and sustainable livelihood. Unasylva No 202.

Temu, A. and Ogweno, D. (2007). Global forestry education guidance and monitoring: How imperative is it? In: Temu, A., Kiwia, A., Kaboggoza, J., Kung'u, J., Chamshama, S. and Chikamai, B. (ED). New perspectives in forestry education. World Agroforestry centre (ICRAF), Nairobi. ISBN 978-92-9059-221-1. 396p.

This is an open-access article published and distributed under the terms and conditions of the $(\mathrm{cc}) \mathrm{EY}$ Creative Commons Attribution 4.0 International License of United States unless otherwise stated. Access, citation and distribution of this article is allowed with full recognition of the authors and the source.

Authors seeking to publish with an International Peer Reviewed Journal should consider www.ijcab.org by writing to the Editor at editor@ijcab.org. The articles must be quality and meet originality test. 